\title{
Some Environmental Factors Affecting Birth Weight, Weaning Weight and Daily Live Weight Gain of Holstein Calves
}

\author{
Erdal Yaylak $^{1 *}$, Hikmet Orhan ${ }^{2}$, Alim Daşkaya ${ }^{3}$ \\ ${ }^{1}$ Department of Animal Science, Faculty of Agricultural, Süleyman Demirel University, 32260 Isparta, Turkey \\ ${ }^{2}$ Faculty of Medicine, Department of Biostatistics and Medical Informatics, Süleyman Demirel University, 32260 Isparta ,Turkey \\ ${ }^{3}$ Veterinarian, Akkoyunlu Village, 35900 Tire, İzmir, Turkey
}

\section{A R T I C L E I N F O}

Article history:

Received 30 March 2015

Accepted 19 June 2015

Available online, ISSN: 2148-127X

Keywords:

Calf

Birth weight

Weaning weight

Holstein

Temperature humidity index

"Corresponding Author:

E-mail: erdalyaylak@sdu.edu.tr

\section{A B S T R A C T}

The present study was conducted to determine some environmental factors affecting birth weight, weaning weight and daily live weight gain of Holstein calves of a livestock facility in Izmir, Turkey. The data on 2091 calves born between the years 2005-2010 were used to assess the relevant parameters. Effects of calving year, calving month, calf gender and the interaction between calving year and calving month on calves' birth weights were highly significant. The overall mean of birth weights was $39.6 \pm 0.15 \mathrm{~kg}$. In addition, effects of calving year, calving month, gender, birth weight, weaning age, calving year $\mathrm{x}$ calving month, calving year $\mathrm{x}$ gender and calving year $\mathrm{x}$ calving month $\mathrm{x}$ gender interactions on weaning weight (WW) and daily live weight gain (DLWG) were highly significant. The overall means of WW and DLWG were respectively found to be $79.7 \pm 0.20 \mathrm{~kg}$ and $525 \pm 2.5 \mathrm{~g}$. A one kilogram increase in birth weight resulted in an increase of $0.89 \mathrm{~kg}$ in weaning weight and a decrease of $1.26 \mathrm{~g}$ in daily live weight gain. Prenatal temperature-humidity index (THI) affected birth weight of calves $\left(R^{2}=0.67\right)$. Increasing THI from 50 to 80 resulted in $3.8 \mathrm{~kg}$ decrease in birth weight.

\section{Introduction}

Growth is defined as the mass increase in animal live weight and divided into two periods as prenatal and postnatal growth. The breeders generally deal with postnatal growth of animals. However, prenatal growth is also as much significant as postnatal growth (Düzgüneş and Eliçin, 1986). Birth weight is an early and easy indicator of prenatal growth. The birth weight is commonly used as an early selection criterion in cattle breeding (Kaygisız et al., 2012). Many researchers reported the medium heritability estimates for birth weight. Heritability estimates for birth weight of Brown Swiss calves given by Kaygisiz (1998), Akbulut et al. (2001) and Tilki et al. (2008) were 0.084, 0.36 and 0.15, respectively and for birth weight of Holstein calves given by Unalan (2009) was 0.328 . Genetic and environmental factors such as dam age, calving weight of dam, mothering ability, nutritional conditions of dam, litter size, gestation length, calving year, season, insemination bull, gender of calf, type of birth, geographical region and altitude may influence birth weight of calf (Sakhare and Ingle, 1983; Sang et al., 1986; Holland and Odge, 1992; Alpan and Arpacik, 1998; Wattiaux, 1996a). During the nursing period, the growth is significantly affected by calve genetics, birth weight, gender of calf, calving season, duration of nursing period, amount of milk or milk replacer intake, total starter intake, environmental temperature, and care practices (Akbulut et al., 1993; Greenwood and Cafe, 2007; Bayril and Y1lmaz, 2010; Bateman et al., 2012 ). Dairy cattle imports and artificial inseminations in Turkey alter the genetic structures of the herds. There are also various differences between herd management practices of livestock facilities. Therefore, determination of birth and weaning weights of calves at different years and herds may provide significant helps to growers in implementation and assessment of herd management practices. The primary objective of the present study is to determine the environmental factors affecting birth weight, weaning weight and daily live weight gain of Holstein calves of a livestock facility in Izmir, Turkey.

\section{Material and Methods}

Research data were supplied from the records of 2091 calves born in a member dairy farm of İzmir Cattle Breeders Association from 2005 to 2010. The data on calving date, birth weight, weaning date and weaning weight were gathered and analyzed. Following the disinfection of umbilical cords and mother's licking, calves were weighed with a scale $( \pm 0.5 \mathrm{~kg})$ and taken into individual pens. Then, $2-3 \mathrm{~kg}$ colostrum milked from their mothers was supplied to calves with a plastic milk bottle. The calves were supplied only with colostrum 
during the first 3 days. Starting from the $4^{\text {th }}$ day, calves were fed with a total of 4 liters milk replacer in two meals morning and evening. Following the first week, water and a calf starter feed were supplied to the calves. The calf starter feed was only used during the first month. Thereafter, in addition to the starter feed, a vetch and barley dry hay mixed with milk was supplied to the calves. Weaning time was decided by the breeders based on growth nature of the calves. Calves were weaned at an average age of 77 days. They were weighed in the morning of the weaning day. Two linear models were used in data analysis.

Model 1:

$\mathrm{Y}_{\mathrm{ijkl}}=\mu+\mathrm{cy}_{\mathrm{i}}+\mathrm{cm}_{\mathrm{j}}+\mathrm{s}_{\mathrm{k}}+(\mathrm{cy} * \mathrm{~cm})_{\mathrm{ij}}+(\mathrm{cy} * \mathrm{~s})_{\mathrm{ik}}+\left(\mathrm{cm}^{*} \mathrm{~s}\right)_{\mathrm{jk}}+(\mathrm{cy} *$ $\left.\mathrm{cm}^{*} \mathrm{~s}\right)_{\mathrm{ijk}}+\mathrm{e}_{\mathrm{ijkl}}$;

Where, $\mathrm{Y}_{\mathrm{ijkl}}$ : Birth weight; $\mu$ : General mean; cy $\mathrm{y}_{\mathrm{i}}$ : Effect of calving year; $\mathrm{cm}_{\mathrm{j}}$ : Effect of calving month; $\mathrm{s}_{\mathrm{k}}$ : Effect of calf gender and interactions $(\mathrm{cy} * \mathrm{~cm})_{\mathrm{ij}},(\mathrm{cy} * \mathrm{~g})_{\mathrm{ik}}$, $\left(\mathrm{cm}^{*} \mathrm{~g}\right)_{\mathrm{jk}},\left(\mathrm{cy} * \mathrm{~cm}^{*} \mathrm{~g}\right)_{\mathrm{ijk}}$ and $\mathrm{e}_{\mathrm{ijkl}}$ : Randomized error.

\section{Model2:}

It was created for weaning weight and daily live weight gain through adding birth weight (bw) and weaning age (wa) into Model 1 as covariate.

The effects of temperature-humidity index (THI) on birth weight and weaning weight were also investigated. Temperature and relative humidity data of the years 20042010 were supplied from İzmir Regional Directorate of Meteorology. To calculate THI values, the formula provided by Kibler $(1964)(\mathrm{THI}=1.8 \times \mathrm{Ta}-(1-\mathrm{RH}) \times$ $(\mathrm{Ta}-14.3)+32$, where THI:Temperature-humidity index, Ta: Atmospheric temperature $\left({ }^{\circ} \mathrm{C}\right), \mathrm{RH}$ : Relative humidity (\%)) was used. A polynomial relationship was identified between monthly THI averages and birth weights of calves and estimation model of the curve was created. GLM/Univariate procedure of SPSS statistical software was used in data analysis and pairwise comparisons were made based on the estimated marginal means and Bonferroni test was applied for multiple comparisons.

\section{Results and Discussion}

\section{Birth Weight}

The least square means and standard errors for birth weights of Holstein calves (BW) are provided in Table 1. Calving year, calving month, calf gender and calving year $x$ calving month interaction had significant effects $(\mathrm{P}<0.01)$ on birth weights. The overall mean of birth weights was $39.6 \pm 0.15 \mathrm{~kg}$. The smallest birth weights (38.1 and $38.4 \mathrm{~kg}$ ) were observed in the years 2005 and 2010 while the highest value $(41.7 \mathrm{~kg})$ was observed in the year 2006. With regard to calving months, the lowest birth weights (38.2 and $38.3 \mathrm{~kg}$ ) were observed in June and November and the highest values were observed in February and April (41.0 and $41.1 \mathrm{~kg}$ ). There was a significant variation in birth weights of the calves based on calving year and calving month. Year effect reflects the environmental conditions such as temperature and relative humidity, feeding, hygiene, and management conditions of dam during gestation (Manzi et al., 2012). Effects of calving year, gender of calf, producing type of calf, feeding conditions through the end of gestation period and climate conditions on birth weight of calves were reported by various studies (Unalan, 2009; Shazzad et al., 2010; Bazzi, 2011; Uzmay et al., 2011; Manzi et al., 2012). The overall mean of birth weights $(39.6 \pm 0.15 \mathrm{~kg})$ of the present study was lower than the values reported by Bush and Nicholson (1986), Başpınar et al. (1998), Johanson and Berger (2003), Uzmay et al. (2010); similar to value reported by Unalan (2009) and Bayril and Y1lmaz (2010) and greater than the values reported by Şahiner and Demir (1998), Akbulut et al. (1993), Bardakçıŏlu (2001), Bilgiç and Alıç (2005) and Kaygısız et al. (2012). Average birth weight of Holstein-like largesize breeds is commonly reported as 40-45 kg (Wattiaux, 1996b). Birth weights of the calves of the present study complied with the general birth weights of the Holstein breed.

The least-squares means and standard errors for birth weights of male and female calves were respectively $41.1 \pm 0.21$ and $38.2 \mathrm{~kg} \pm 0.21 \quad(\mathrm{P}<0.05)$. Birth weights of male calves were about $2.9 \mathrm{~kg}(7.7 \%)$ higher than the birth weights of female calves (Table 1). Previous researchers also reported higher birth weights of male calves (Unalan, 2009; Uzmay et al., 2010; Bazzi, 2011; Manzi et al., 2012). Male calves usually have higher birth weights because of longer gestation periods and higher androgen hormone intensity of fetus serum (Uzmay et al., 2010; Manzi et al., 2012). Thusly, a day prolongation in gestation period result in $0.5 \mathrm{~kg}$ increase in birth weights (Wattiaux, 1996a).

To assess the effects of temperature-humidity index (THI) on birth weights, average THI values were calculated for the birth month and before 2 months from the birth month. Variation of birth weights and THI values based on calving months are presented in Figure 1. There was a polynomial relationship between mean THI values and birth weight values of calving month (Figure $2)$. Degree of accuracy $\left(R^{2}\right)$ of the relationship between THI and birth weight was 0.67. Annual and monthly variations in care, feeding and climate conditions might have resulted in such variations. Considering the polynomial relationship between THI values of calving month and birth weights, it was observed that birth weights initially decreased and then increased with increasing THI values (Figure 2). While birth weights linearly decreased with increasing THI, an increase was observed at THI values of 70 or above (September and October). Birth weights at THI values of 50, 60, 70 and 80 were respectively estimated from equation $\left(Y=0.009 \mathrm{x}^{2}\right.$ $-1.295 \mathrm{x}+82.13$; $\mathrm{x}=\mathrm{THI})$ as $39.9 \mathrm{~kg}, 36.8 \mathrm{~kg}, 35.6 \mathrm{~kg}$ and $36.1 \mathrm{~kg}$. There was $3.8 \mathrm{~kg}$ difference in birth weights of calves born at THI values of 50 and 80 . Decrease in birth weights at high THI values was mainly because of negative impacts of heat stress on fetus development through the end of gestation period. Thusly, Collier et al. (1982) reported that calves of Holstein cows exposed to heat stress during the last $1 / 3$ of gestation period had $3 \mathrm{~kg}$ less birth weights than the cows stayed at shade. Since 
calve weights increase from 4 to $45 \mathrm{~kg}$ during the last $1 / 3$ of the gestation period, such a prenatal period is highly critical for birth weights of the calves (Wattiaux, 1996a). Due to the fact that the heat stress had negative impact on the fetus development, the pregnant cows should be subjected to cooling treatment during the dry period.

\section{Weaning weight}

The least square means and standard errors for weaning weights (WW) are presented in Table 1. Calving year, calving month, calf gender, birth weight, weaning age, calving year $\mathrm{x}$ calving month, calving year $\mathrm{x}$ calf gender and calving year $\mathrm{x}$ calving month $\mathrm{x}$ calf gender interactions had highly significant effects $(\mathrm{P}<0.01)$ on weaning weight. The overall mean of weaning weight was $79.7 \pm 0.20 \mathrm{~kg}$. With regard to calving year, the lightest weaning weights $(76.8$ and $77.1 \mathrm{~kg}$ ) were observed in the years 2006 and 2007 and the heaviest weaning weight $(84.3 \mathrm{~kg})$ was observed in the year 2008 . With regard to weaning months, the lowest weaning weight $(77.8 \mathrm{~kg})$ was observed in April and the highest value $(82.0 \mathrm{~kg})$ in February. The overall mean of weaning weight of the present study was smaller than the value reported by
Başpınar et al. (1998) and higher than the values reported by Akbulut et al. (1993), Bayril and Yilmaz (2010) and Uzmay et al. (2011). With regard to weaning weight of calves, Başpınar et al. (1998) reported the highest value in winter and the lowest in summer and Akbulut et al. (1993) reported the highest values in summer and fall seasons. In the present study, weaning weight was low in spring and high in winter months.

The least square means for weaning weight was $81.6 \pm 0.28 \mathrm{~kg}$ in males and $77.9 \pm 0.28 \mathrm{~kg}$ in females $(\mathrm{P}<0.05)$. While birth weights of male calves of the present study were $7.7 \%$ higher than the female calves, the ratio receded to $4.7 \%$ in weaning. Weight gain until weaning was in favor of females. Although male calves were not able to exhibit their birth weight advantage at weaning, they still have higher weaning weights than the female calves just because of longer gestational period or higher androgen level (Manzi et al., 2012). Similar to findings of the present study, Yanar et al. (1993) also reported higher weaning weights for males than females, but Bayril and Y1lmaz (2010) was not able to identify any significant differences in weaning weights of genders.

Table 1 Least square means, significance and multiple comparison test results for birth weight (kg), weaning weight $(\mathrm{kg})$ and daily weight gain $(\mathrm{g})$ of Holstein calves

\begin{tabular}{|c|c|c|c|c|c|c|c|c|c|c|}
\hline \multirow{2}{*}{ Factors } & & \multicolumn{3}{|c|}{ Birth weight $(\mathrm{kg})$} & \multicolumn{3}{|c|}{ Weaning weight $(\mathrm{kg})$} & \multicolumn{3}{|c|}{ Daily weight gain $(\mathrm{g})$} \\
\hline & & $\mathrm{n}$ & Mean & $\mathrm{SE}$ & $\mathrm{n}$ & Mean & SE & $\mathrm{n}$ & Mean & SE \\
\hline \multirow{7}{*}{$\begin{array}{l}\text { Overall Mear } \\
\text { Birth year }\end{array}$} & & 2091 & $\begin{array}{l}39.6 \\
* * *\end{array}$ & 0.15 & 1853 & $\begin{array}{l}79.7 \\
* * *\end{array}$ & 0.20 & 1853 & $\begin{array}{l}525 \\
* * *\end{array}$ & 2.5 \\
\hline & 2005 & 268 & $38.1^{\mathrm{c}}$ & 0.38 & 258 & $79.5^{\mathrm{c}}$ & 0.48 & 258 & $513^{\mathrm{cd}}$ & 6.1 \\
\hline & 2006 & 224 & $41.7^{\mathrm{a}}$ & 0.42 & 221 & $77.1^{\mathrm{d}}$ & 0.53 & 221 & $490^{\mathrm{d}}$ & 6.8 \\
\hline & 2007 & 232 & $40.1^{\mathrm{ab}}$ & 0.43 & 214 & $76.8^{\mathrm{d}}$ & 0.55 & 214 & $490^{\mathrm{d}}$ & 7.0 \\
\hline & 2008 & 280 & $40.4^{\mathrm{ab}}$ & 0.42 & 276 & $84.3^{\mathrm{a}}$ & 0.52 & 276 & $587^{\mathrm{a}}$ & 6.6 \\
\hline & 2009 & 596 & $39.2^{\mathrm{bc}}$ & 0.24 & 563 & $79.3^{\mathrm{c}}$ & 0.32 & 563 & $523^{\mathrm{c}}$ & 4.1 \\
\hline & 2010 & 491 & $38.4^{\mathrm{c}}$ & 0.26 & 321 & $81.5^{\mathrm{b}}$ & 0.46 & 321 & $550^{\mathrm{b}}$ & 5.9 \\
\hline \multirow[t]{13}{*}{ Birth month } & & & $* * *$ & & & $* *$ & & & $* *$ & \\
\hline & January & 182 & $40.2^{\mathrm{a}-\mathrm{c}}$ & 0.46 & 169 & $79.1^{\mathrm{ab}}$ & 0.59 & 169 & $517 \mathrm{ab}$ & 7.6 \\
\hline & February & 144 & $41.0^{\mathrm{a}}$ & 0.51 & 117 & $82.0^{\mathrm{a}}$ & 0.74 & 117 & $549^{\mathrm{a}}$ & 9.5 \\
\hline & March & 132 & $40.2^{\mathrm{a}-\mathrm{c}}$ & 0.68 & 119 & $80.2^{\mathrm{ab}}$ & 0.86 & 119 & $529^{\mathrm{ab}}$ & 11.1 \\
\hline & April & 146 & $41.1^{\mathrm{a}}$ & 0.54 & 127 & $77.8^{\mathrm{b}}$ & 0.71 & 127 & $499^{\mathrm{b}}$ & 9.2 \\
\hline & May & 160 & $39.5^{\mathrm{a}-\mathrm{c}}$ & 0.69 & 153 & $78.0^{\mathrm{b}}$ & 0.84 & 153 & $505^{\mathrm{ab}}$ & 10.8 \\
\hline & June & 192 & $38.2^{\mathrm{c}}$ & 0.45 & 178 & $80.2^{\mathrm{ab}}$ & 0.56 & 178 & $530^{\mathrm{ab}}$ & 7.3 \\
\hline & July & 188 & $38.6^{\mathrm{bc}}$ & 0.49 & 157 & $80.4^{\mathrm{ab}}$ & 0.62 & 157 & $535^{\mathrm{ab}}$ & 8.0 \\
\hline & August & 187 & $38.9^{\mathrm{a}-\mathrm{c}}$ & 0.48 & 169 & $80.5^{\mathrm{ab}}$ & 0.61 & 169 & $532^{\mathrm{ab}}$ & 7.9 \\
\hline & September & 153 & $40.7^{\mathrm{ab}}$ & 0.52 & 144 & $79.9^{\mathrm{ab}}$ & 0.66 & 144 & $529^{\mathrm{ab}}$ & 8.4 \\
\hline & October & 187 & $39.8^{\mathrm{a}-\mathrm{c}}$ & 0.46 & 169 & $80.3^{\mathrm{ab}}$ & 0.57 & 169 & $536^{\mathrm{ab}}$ & 7.3 \\
\hline & November & 202 & $38.3^{\mathrm{c}}$ & 0.43 & 177 & $79.7^{\mathrm{ab}}$ & 0.56 & 177 & $524^{\mathrm{ab}}$ & 7.2 \\
\hline & December & 218 & $39.2^{\mathrm{a}-\mathrm{c}}$ & 0.45 & 174 & $78.7^{\mathrm{b}}$ & 0.61 & 174 & $516^{\mathrm{ab}}$ & 7.8 \\
\hline \multirow[t]{3}{*}{ Gender of cal } & & & $* * *$ & & & $* * *$ & & & $* * *$ & \\
\hline & Female & 1039 & 38.2 & 0.21 & 935 & 77.9 & 0.28 & 935 & 500 & 3.5 \\
\hline & Male & 1052 & 41.1 & 0.21 & 918 & 81.6 & 0.28 & 918 & 551 & 3.6 \\
\hline \multicolumn{2}{|c|}{ Birth year x Birth month } & & $* * *$ & & & $* * *$ & & & $* * *$ & \\
\hline \multicolumn{2}{|c|}{ Birth year x Gender } & & NS & & & $* * *$ & & & $* * *$ & \\
\hline \multicolumn{2}{|c|}{ Birth month x Gender } & & NS & & & NS & & & NS & \\
\hline \multicolumn{2}{|c|}{ Birth year x Birth month x Gender } & & NS & & & $* * *$ & & & $* * *$ & \\
\hline \multicolumn{2}{|c|}{ Birth weight } & & - & & & $0.89 * * *$ & & & $-1.26 * *$ & \\
\hline \multicolumn{2}{|l|}{ Weaning age } & & - & & & $0.41 * * *$ & & & $-1.08 * * *$ & \\
\hline \multicolumn{2}{|l|}{$\mathrm{R}^{2}$} & & 0.21 & & & 0.60 & & & 0.43 & \\
\hline
\end{tabular}




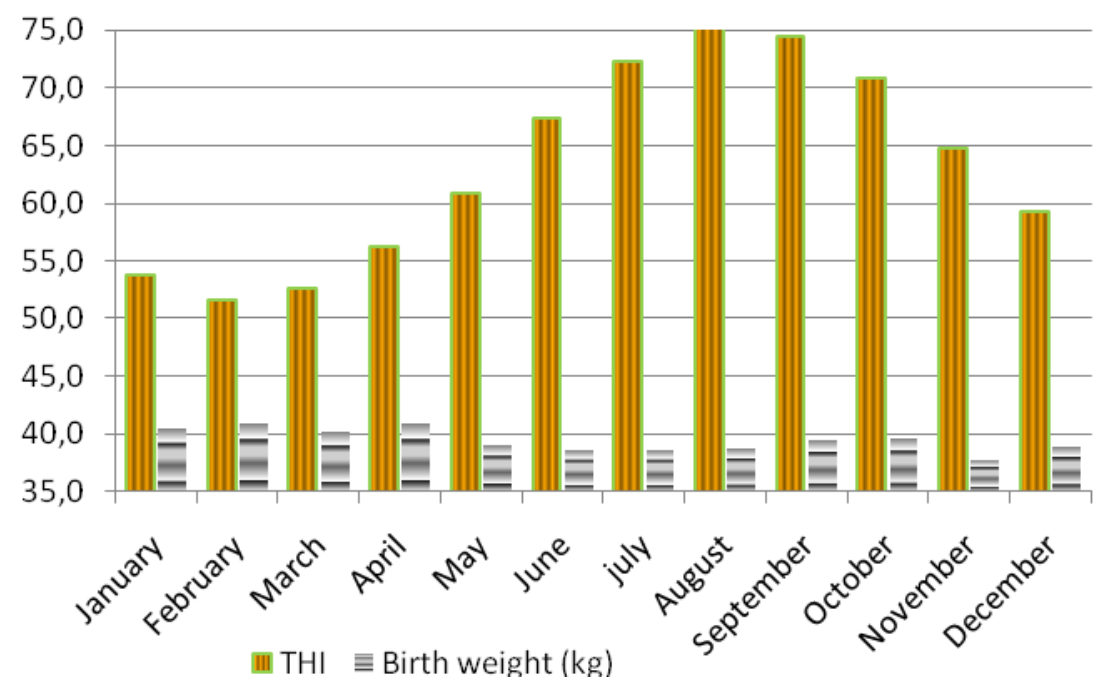

Figure1 Monthly variations in birth weight and temperature-humidity index (THI) values.

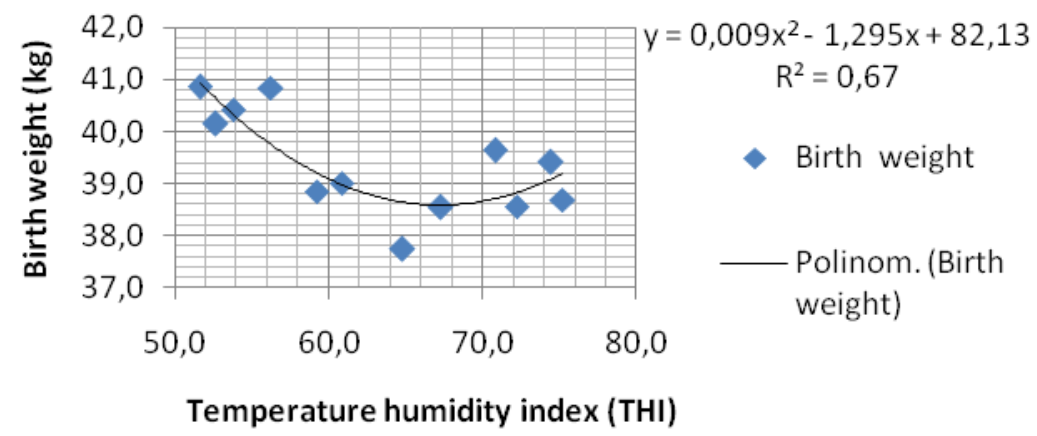

Figure 2 Variation of birth weights based on temperature-humidity index

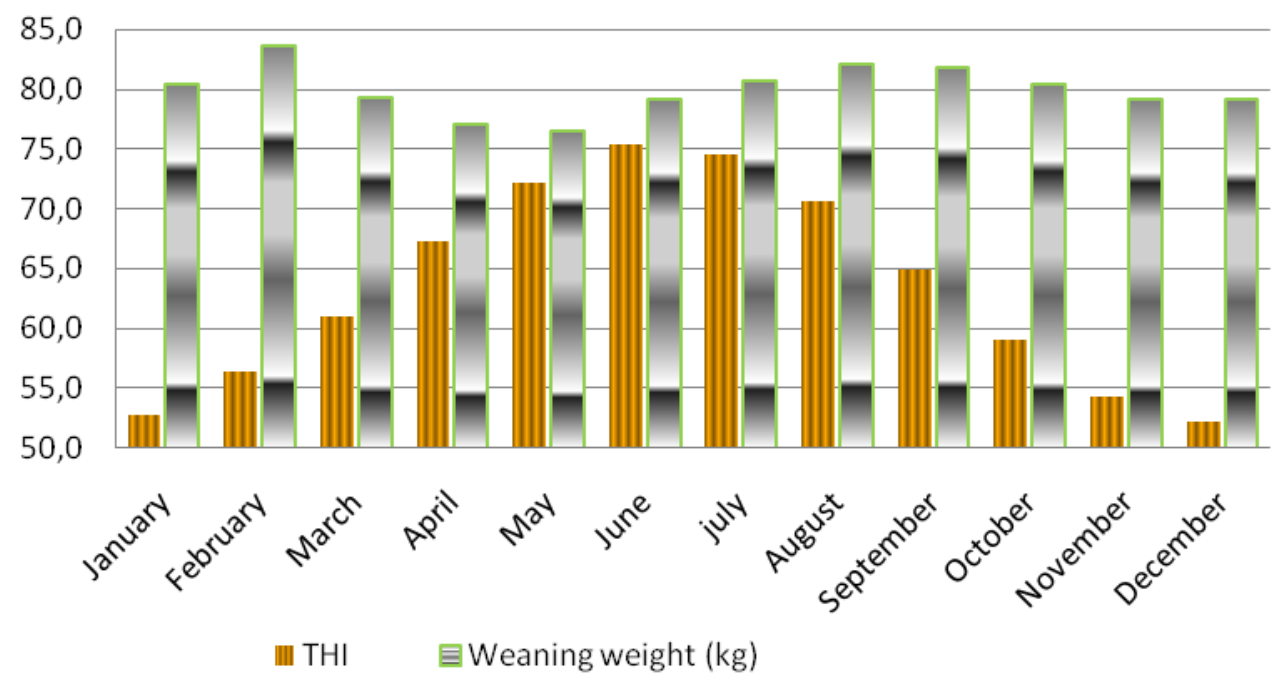

Figure 3 Monthly variations in weaning weight and temperature humidity index (THI) values 
Weaning weight was influenced by birth weight and weaning age (Table 1). A one kilogram increase in birth weight resulted in $0.89 \mathrm{~kg}$ increase in weaning weight and a day prolongation in weaning age resulted in $0.41 \mathrm{~kg}$ increase in weaning weight. Bayril and Y1lmaz (2010) reported $0.93 \mathrm{~kg}$ increase in weaning weight of Holstein calves with a one $\mathrm{kg}$ increase in birth weight and Yaylak et al. (2013) reported $1.09 \mathrm{~kg}$ increase in Brown Swiss and Simmental calves. Besides increasing weaning weights and higher birth weights also increase calf mortality within 48 hours of birth and dystocia risk (Johanson and Berger, 2003; Uzmay et al., 2010). Therefore, ideal birth weights should be aimed in selection.

Again, average THI values were calculated for the birth month and after 2 months from the birth month to assess the effects of THI on weaning weights. Monthly variations in temperature-humidity index values and weaning weights are presented in Figure 3. Weaning weights decreased with increasing temperature-humidity index values and vice versa. However, as it was between birth weight and THI, a relationship was not observed also between weaning weights and THI. Lower weaning weights in spring were mainly because of increasing disease-causing microorganisms and disease carrying flies together with increasing temperatures. Thusly, diseases are mostly observed in spring months at this region (Yaylak et al., 2010). High temperature also decreases feed consumption of calves. This suggests that the variation in temperature and other environmental conditions among birth years and birth months had significant effect on the calves at weaning.

\section{Daily live weight gain}

The least square means and standard errors for daily live weight gain (DLWG) of calves are provided in Table 1. Effects of calving year, calving month, calf gender, birth weight, weaning age, calving year x calving month, calving year $\mathrm{x}$ calf gender and calving year $\mathrm{x}$ calving month $x$ calf gender interactions on daily live weight gain were found to be highly significant $(\mathrm{P}<0.01)$. The overall mean DLWG of calves was $525 \pm 2.5 \mathrm{~g}$ with the lowest value $(490 \mathrm{~g})$ in the years 2006 and 2007 and the highest value $(587 \mathrm{~g})$ in the year $2008(\mathrm{P}<0.05)$. With regard to calving months, the lowest DLWG value (499 g) was observed in April, the highest value (549 g) was observed in February. The least square mean DLWG values of male and female calves were respectively observed as 551 and $500 \mathrm{~g}$. A one kilogram increase in birth weight resulted in $1.26 \mathrm{~g}$ and a day prolongation in weaning age resulted in $1.08 \mathrm{~g}$ decrease in DLWG of calves $(\mathrm{P}<0.01)$. The present mean DLWG was higher than the value reported by Uzmay et al., 2011. Daily live weight gains of the calves to weaning age should be 550-600 g (Kumlu, 1999). Thus, current values were found to be sufficient.

\section{Conclusions}

Current findings revealed that birth weight, weaning weight and daily live weight gains of Holstein calves were significantly affected by birth year, birth month, calf gender and some interactions between these variables.
However, birth weight, weaning weight and daily live weight gains complied with Holstein breed in general. Prenatal temperature-humidity index (THI) affected birth weight of calves. Birth weights of calves with low THI values during the last trimester of gestation period were higher than the calves with high THI values throughout the same period. Variations in birth weight, weaning weight and daily live weight gain of calves were mainly because of climate conditions, housing conditions, feeding and herd management practices of the dams during gestations and suckling period of calves. In a selection to be made, such effects of environmental factors should be tried to be eliminated. Determination of birth weights and weaning weights of calves may also provide various supports in practical implementations of livestock facilities. Prevention of heat stress exerted over cows in housing systems, therefore the provision of proper care and feeding practices may also improve birth weights which could negatively affected by the heat stress.

\section{References}

Akbulut Ö, Tüzemen N, Aydın R. 1993. Erzurum şartlarında Siyah Alaca sığırların verimi. 2: Doğum ağırlığı, büyüme ve yaşama gücü özellikleri. Türk Vet. Hay. Derg., 17(3): 193-200.

Akbulut O, Bayram B, Yanar M. 2001. Yarı entansif şartlarda yetiştirilen Esmer ve Siyah Alaca buzağıların doğum ağırlı̆̆ına ait fenotipik ve genetik parametre tahminleri. Lalahan Hay. Araşt. Derg., 41(2): 11-20.

Alpan O, Arpacık R. 1998. Sığır Yetiştiriciliği. 2. Baskı, Şahin Matbaas1, Ankara.

Bardakçıŏlu HE. 2001. Bireysel kulübelerde barındırılan Holştayn buzağıların büyüme ve yaşama gücüne; doğum ağırlı̆̆ı, cinsiyet ve doğum mevsiminin etkileri. İstanbul Üniv. Vet. Fak. Derg., 27(2): 439-458.

Başpınar H, Oğan M, Batmaz E S, Balcı F, Karakaş E, Baklacı C. 1998. Esmer ve Holştayn buzağıların büyüme ve yaşama gücüne etki eden bazı çevresel faktörler. Lalahan Hay. Araşt. Derg., 38(2):19-31.

Bateman HG, Hill TM, Aldrich JM, Schlotter RL, Firkins, JL. 2012. Meta analysis of the effect of initial serum protein concentration and empirical prediction model for growth of neonatal Holstein calves through 8 weeks of age. J. Dairy Sci., 95: 363-369

Bayrıl T, Yılmaz O. 2010. Kazova Vasfi Diren Tarım İşletmesinde yetiştirilen Siyah Alaca buzağılarda büyüme performansı ve yaşama gücü. YYU Vet Fak. Derg., 21(3): 169-173.

Bazzi H. 2011. Evaluation of non-genetic factors affecting birth weight in Sistani cattle. J. Anim. Vet. Adv., 10: 3095-3099.

Bilgiç N, Alıç D. 2005. Siyah Alaca buzağıların doğum ağırlıklarına ait genetik ve fenotipik parametre tahminleri. Ankara Üniv. Tar. Bil. Der., 10(1):72-75.

Bush RS, Nicholson JWB. 1986. The Effects of weaning schedule, duration of milk feeding and fishmeal on calf performance. Can. J. Anim. Sci., 66: 691-698.

Collier RJ, Doelger SG, Head HH, Thatcher WW, Wilcows CJ. 1982. Effects of heat stress during on maternal hormone concentrations, calf birth weight and postpartum milk yield of Holstein cows. J. Anim. Sci., 54: 309-319.

Düzgüneş O, Eliçin A. 1986. Hayvan Yetiştirme İlkeleri. Ankara Üniversitesi Ziraat Fakültesi Yay: 978, Ders Kitabı: 288. Ankara.

Greenwood PL, Cafe LM. 2007. Prenatal and pre-weaning growth and nutrition of cattle: long-term consequences for beef production. Animal, 1:9:1283-1296.

Holland MD, Odge KG. 1992. Factors affecting calf birth weight: A review. Theriogenology, 38: 769-798. 
Johanson JM, Berger PJ. 2003. Birth weight as a predictor of calving ease and perinatal mortality in Holstein cattle. J. Dairy Sci., 86:3745-3755.

Kibler HH. 1964. Environmental physiology and shelter engineering. LXVII. Thermal effects of various temperaturehumidity combinations on Holstein cattle as measured by eight physiological responses, Res. Bull. Missouri Agric. Exp. Station. 862.

Kaygisiz A. 1998. Estimates of genetic and phenotypic parameter for birth weight in Brown and Simmental Calves raised at Altindere State Farm. Turk J. Vet. Anim. Sci., 22:527-535.

Kaygisız A, Bakır G, Yılmaz I. 2012. Genetic parameters for direct and maternal effects and an estimation of breeding values for birth weight of Holstein Friesian calves. Bulg. J. Agric. Sci., 18: $117-124$

Kumlu S. 1999. Damızlık ve Kasaplık Sığır Yetiştirme, Setma Matbaacilık, Ankara.

Manzi M, Junga JO, Ebong C, Mosi RO. 2012. Factors affecting pre and post-weaining growth of six cattle breed groups at Songa Research station in Rwanda. Liv. Res. Rural Dev, Vol. 24 Article \#68. Available May 25, 2014, (http://www.Irrd24/4/manz24068.htm)

Sakhare PG, Ingle UM. 1983. Genetic and non-genetic factors affecting birth weight in Holstein x Sahiwal crossbred calves. Indian J. Dairy Sci., 36: 184-186.

Sang BC, Cho Y, Kim KK. 1986. Repetability estimates of gestation length and birth weight and the environmental effects on these traits in dairy cattle. Korean J. Anim Sci., 28: 184-187.

Shahzad F, Yaqoob M, Younas M, Farooq U, Sher F, Asim M, Qamar S, Akbar M, Irshad I. 2010. Factors affecting the birth weight of Cholistani cattle calves. Pak. Vet. J., 30(4): 247-248.

Şahiner Z, Demir H. 1998. Siyah Alaca sığırlarda yaşama gücü, büyüme, ergin canlı ağırlık ve vücut ölçülerini etkileyen bazı çevre faktörleri üzerinde araştırmalar. İstanbul Üniv. Vet. Fak. Derg., 24(1): 61-78.
Tilki M, Saatçı M, Çolak M. 2008. Genetic parameters for direct and maternal effects and estimation of breeding values for birth weight in Brown Swiss Cattle. Turk J. Vet. Anim. Sci., 32: 287292.

Unalan A. 2009. Estimation of genetic parameters and correlations among some body measurements of Holstein calves and effects of these measurements on calving difficulty. J. Anim. Vet. Adv., 8 (8): 1589-1594.

Uzmay C, Kaya İ, Ayyılmaz T. 2010. Analysis of risk factors for dystocia in a Turkish Holstein herd. J. Anim. Vet. Adv., 9 (20): 2571-2577.

Uzmay C, Ayyılmaz T, Kaya İ, Ünlü HB, Bertan B. 2011. Türkiye DSYMB döl kontrolü projesinde çekirdek sürü islah sistemi ilkeleri uygulanarak etkinliğin artırılması olanakları konulu alt proje kapsamında aday boğa kullanımı, düvelerde doğum zorluğu ve yavrularda gelişme özelliklerine ait ön sonuçlar. Hay. Üret., 52 (1): 1-8.

Wattiaux MA. 1996a. Technical dairy guide. Reproduction and genetic selection. Babcock Institute for International Dairy Research and Development, University of Wisconsin.

Wattiaux MA. 1996b. Technical dairy guide. Raising dairy heifers. Babcock Institute for International Dairy Research and Development, University of Wisconsin.

Yanar M, Tüzemen N, Ockerman HW. 1993. The effect of weaning ages on the growth characteristics and feed efficiencies of Simmental calves. Agr. Equip. Int. 45(3-4): 38-39.

Yaylak E, Kaya İ, Cundar V, Gevrek A. 2010. Damage types, causes of damage and herd leaving ages in dairy cattle under the scope of livestock insurance and subject to compensation in some districts of Izmir Province of Turkey. Afr. J. Agr. Res., 6: 1265-1273.

Yaylak E, Şayan Y, Kulay T, Güley Z. 2013. İthal edilen farklı ırk sığırlarda kolostrum kalitesi ve buzağılarının performansları. 2011-OMYO-001 nolu Proje Raporu. 